\title{
PEMBINAAN ANAK DIDIK PEMASYARAKATAN KASUS NARKOTIKA DI LEMBAGA PEMBINAAN KHUSUS ANAK BERDASARKAN UNDANG-UNDANG NOMOR 11 TAHUN 2012 TENTANG SISTEM PERADILAN PIDANA ANAK
}

\author{
Rizki Hamonangan Simanjuntak \\ Politeknik Ilmu Pemasyarakatan \\ Email : rizkyhs54@yahoo.com
}

\begin{abstract}
Abstrak
Masalah penyalahgunaan narkoba telah menjadi masalah nasional dan internasional yang tidak pernah berakhir untuk dibahas. Hampir setiap hari ada berita tentang. Kesadaran narkoba dapat menyebabkan kerusakan fisik, mental, emosional dan sikap di masyarakat. Perlindungan anak adalah seluruh kegiatan untuk menjamin dan melindungi anak-anak dan hak-hak mereka untuk dapat hidup, tumbuh dan berkembang dan mengambil bagian secara optimal sesuai dengan harga diri dan martabat manusia, dan mendapatkan perlindungan terhadap kekerasan dan diskriminasi. UndangUndang Nomor 11 Tahun 2012 tentang Sistem Peradilan Pidana Anak benar-benar menjamin perlindungan kepentingan terbaik Anak-anak yang berurusan dengan hukum sebagai penerus bangsa. Kepadatan, sarana dan prasarana menjadi salah satu faktor penghambat pelaksanaan program pembinaan siswa di bidang narkotika di pusat perawatan remaja.
\end{abstract}

Kata kunci: anak, program, sistem peradilan.

\begin{abstract}
The issue of drug abuse has become a national and international issue that has never ending to be discussed. Almost every day there is news about. Drug awareness can cause physical damage, mental, emotional and attitudes in society. Child protection is entire activity to guarantee and protect children and their rights to be able to living, growing and developing and taking part optimally in accordance with humane esteem and dignity, and obtaining protection against violence and discrimination. Law Number 11 Year 2012 on the Children Criminal Justice System really guarantees the protection of the best interests of the Children who deal with the law as the successor of the nation. Overcrowding, facilities and infrastructure become one of the factors inhibiting the implementation of the program of guidance of students in narcotics in juvenile treatment center.
\end{abstract}

Keywords: child, program, criminal justice system.

\section{PENDAHULUAN}

Indonesia sebagai negara Pancasila dan memiliki Undang-Undang Dasar Negara Republik Indonesia 1945 wajib memberikan perlindungan kepada setiap warga negara termasuk anak khususnya. Perlindungan terhadap anak sebagai upaya menciptakan generasi penerus bangsa. Bentuk perlindungan tersebut diantaranya memberikan kenyamanan, keamanan, kesehatan, memberikan pendidikan yang cukup, dan lain-lain. Berbicara mengenai

anak yang berhadapan dengan hukum, perlindungan anak telah diberikan oleh pemerintah dengan mengeluarkan peraturan perundang-undangan. Peraturan perundang-undangan tersebut salah satunya adalah Undang-Undang Nomor 11 Tahun 2012 tentang Sistem Peradilan Pidana Anak. Pada Pasal 1 Angka 2 Undang-Undang Nomor 11 Tahun 2012 tentang Sistem Peradilan Pidana Anak menegaskan bahwa Anak yang Berhadapan dengan Hukum adalah anak yang berkonflik dengan hukum, anak yang 
menjadi korban tindak pidana dan anak yang menjadi saksi tindak pidana sedangkan Pasal 1 angka 3 menyatakan bahwa Anak yang Berkonflik dengan Hukum yang selanjutnya disebut Anak adalah anak yang telah berumur 12 (dua belas) tahun, tetapi belum berumur 18 (delapan belas) tahun yang diduga tahun 2016 adalah 2188 orang anak, tahun 2017 berjumlah 2830 orang anak dan pada agustus 2018 berjumlah 2286 orang anak. Berdasarkan data tersebut menerangkan bahwa jumlah anak pidana bersifat fluktuatif, menurunnya angka jumlah anak pidana tidak berarti membuktikan bahwa program pembinaan anak pidana berjalan dengan optimal.

Berbicara mengenai program pembinaan bagi anak pidana saat ini pada Lembaga Pembinaan Khusus Anak hanya menjadi tugas dan tanggung jawab pihak Pembina dalam lembaga saja sehingga restorative jutice tidak tercapai. Masalah anak yang berhadapan dengan hukum harus sampai pada tahap pembinaan anak pidana pada Lembaga Pembinaan Khusus Anak meskipun dalam Undang-Undang Nomor 11 Tahun 2012 tentang Sistem Peradilan Pidana Anak menekankan terwujudnya diversi yang bertujuan untuk mencapai keadilan restorative hanya dapat terlaksana sampai pada tahap proses persidangan anak. Menurut Pasal 1 angka 7 yang dimaksud dengan diversi adalah pengalihan penyelesaian perkara Anak dari proses peradilan pidana ke proses di luar peradilan pidana. Menurut Pasal 1 angka 6 yang terkait untuk bersama-sama mencar penyelesaian yang adil dengan menekankan pemulihan kembali pada keadaan semula dan bukan pembalasan.

Berdasarkan hal tersebut, pembinaan di Lembaga Pembinaan Khusus Anak tidak hanya melibatkan pembina, petugas, tenaga ahli professional dan anak melakukan tindak pidana (Hukum \& Ummah, 2017). Pada praktiknya, jumlah anak berhadapan dengan hukum yang sedang menjalani pembinaan di Lembaga Pembinaan Khusus Anak dan dikenal dengan istilah anak pidana sangat banyak. Berdasarkan data Direktorat Jenderal Pemasyarakatan, jumlah anak pidana pada pidana semata akan tetapi demi kepentingan terbaik bagi anak, pembinaan di Lembaga Pembinaan Khusus Anak harus melibatkan keluarga, korban, keluarga korban dan masyarakat agar terwujudnya resosialisasi dan rehabilitasi anak.

\section{METODE}

Pendekatan terhadap masalah ini adalah pendekatan yuridis empiris, dimana yang diteliti adalah norma-norma hukum yang berlaku dan pelaksanaannya. Jadi hukum diidentikkan sebagai norma peraturan perundang-undangan. Selain itu, penelitian juga dilakukan di Lembaga Pembinaan Khusus Anak Kelas I Tangerang.

Secara empiris hukum diidentikan sebagai perilaku mempola dan pemahaman makna sosial. Pembahasan dilakukan dengan menggunakan pendekatan sociolegal dalam pembahasan di kaji mencakup faktor-faktor eksternal di luar hukum.

\section{HASIL DAN PEMBAHASAN}

\subsection{Pembinaan Anak Pidana di Lembaga Pembinaan Khsus Anak.}

Lembaga Pembinaan Khusus Anak merupakan salah satu lembaga pembinaan bagi anak pidana terbesar di Indonesia. Fungsi Lembaga Pembinaan Khusus Anak ditujukan sebagai lembaga pendidikan dan pembinaan. Sebaga unit teknis di bidang pemasyarakatan, maka Lembaga Pembinaan Khusus Anak mengemban fungsi yang spesifik dan perlu penajaman atas orientasi pembinaannya. Pengertian tersebut sekaligus menempatkan anak pidana sebagai bagian dari manusia (anak) 
Indonesia seutuhnya yang diharapkan memiliki potensi dan dapat mempunyai tanggung jawab untuk masa depannya. Lembaga Pembinaan Khusus Anak memiliki program pembinaan dan pelatihan adalah sebagai berikut:

\section{a. Pendidikan Formal dan Non Formal}

Pendidikan formal di dalam Lembaga Pembinaan Khusus Anak dimulai dari tingkat Sekolah Dasar (Paket A), Sekolah Menengah Pertama (Paket B), dan Sekolah Menengah Atas (Paket C). Pendidikan non formal ditujukan kepada anak pidana untuk mengasah bakat dan keterampilan agar mereka mempunyai bekal setelah kembali ke dalam masyarakat. Adapun program non formal yang terdapat dalam Lembaga Pembinaan Khusus Anak tersebut adalah pelatihan bengkel, automotive, pelatihan cukur rambut dst.

b. Pembinaan Konseling dan Keagamaan Pembinaan ini bertujuan untuk perbaikan diri dari anak pidana. Hasil penelitian menunjukkan di Lembaga Pembinaan Khusus Anak menyediakan suatu ruang yang digunakan untuk program konseling. Ruangan ini selalu terbuka bagi anak pidana yang memerlukan adanya pembinaan atau perhatian yang lebih banyak sehingga pihak terkait harus mengakomodir hal tersebut. Selain konseling, pembinaan diisi pula oleh kegiatan keagamaan yang merupakan pembinaan wajib di Lembaga Pembinaan Khusus Anak. Pada pelaksanaannya, program pembinaan kepada anak pidana banyak menemukan kendala. Kendala tersebut antara lain pembinaan tidak di dukung oleh pembina yang memahami permasalahan anak. Kondisi yang demikian juga tidak di dukung oleh sarana dan prasarana yang memadai dikarenakan struktur bangunan juga masih kurang ideal serta kurangnya partisipasi dan bantuan dari pihak luar, termasuk keluarga dan masyarakat.

\subsection{Pembaharuan Pembinaan Anak Pidana dalam Perspektif Restorative Justice di Lembaga Pembinaan Khusus Anak}

Pembaharuan pembinaan bagi anak pidana dapat dikatakan sebagai pembaruan hukum pidana. Pembaharuan hukum pidana menurut Barda Nawawi Arief, disebutkan sebagai berikut:

"... makna dan hakikat pembaruan hukum pidana (penal reform) berkaitan erat dengan latar belakang dan urgensi diadakannya pembaruan hukum pidana itu sendiri. Pembaruan hukum (pidana) pada hakikatnya mengandung makna, suatu upaya untuk melakukan reorientasi dan reformasi hukum pidana yang sesuai dengan nilai-nilai sentral sosiopolitik, sosiofilosofis, sosiokultural masyarakat Indonesia yang melandasi kebijakan sosial, kebijakan kriminal dan kebijakan penegakan hukum di Indonesia. Secara singkat dapatlah dikatakan, bahwa pembaruan hukum pidana pada hakikatnya harus ditempuh dengan pendekatan yang berorientasi pada kebijakan (policy oriented approach) dan sekaligus pendekatan yang berorientasi pada nilai (value-oriented approach)."

Berdasarkan hal tersebut, maka dapat dikatakan bahwa pembaharuan pembinaan bagi anak pidana merupakan bagian dari pembaharuan hukum pidana. Pembaharuan hukum pidana pada hakikatnya merupakan upaya melakukan peninjauan dan penilaian kembali (reorientasi dan re-evaluasi) nilai-nilai sosio-politik, sosio-filosofis, sosio-kultural yang melandasi dan memberi isi terhadap muatan normatif dan substantif hukum pidana yang dicita-citakan" (Di et al., 2017).

Nilai filosofis dari bangsa Indonesia adalah Pancasila sehingga pembaharuan sistem hukum nasional idealnya harus berlandaskan Pancasila. Menurut Barda Nawawi Arief, apabila dijabarkan lebih lanjut, maka sistem hukum nasional adalah sistem hukum nasional yang berlandas-kan/berorientasi 
pada tiga pilar/nilai keseimbangan Pancasila, yaitu:

a. berorientasi pada nilai-nilai "Ketuhanan" (bermoral religius);

b. berorientasi pada nilai-nilai "Kemanusiaan" (humanistik); dan

c. berorientasi pada nilai-nilai "Kemasyarakatan" (nasionalistik; demokratik; berkeadilan sosial).

Bertolak dari hal tersebut maka pembinaan anak pidana harus berorientasi pada nilai Ketuhanan, berorientasi pada nilai Kemanusiaan, berorientasi pada nilai Kemasyarakatan. Pembinaan anak pidana harus berorientasi pada nilai ketuhanan karena merupakan wujud ketaqwaan kepada Tuhan Yang Maha Esa. Anak (termasuk anak pidana) harus dianggap sebagai amanah yang harus di jaga dan merupakan tanggung jawab orang tua, keluarga, masyarakat dan pemerintah dan negara.

Pembinaan anak pidana harus berorientasi pada nilai kemanusiaan harus sesuai dengan perlindungan anak pidana. Pembinaan anak pidana harus memiliki program yang harus dapat memanusiakan anak, mengasuh, membina, membimbing anak pidana. Pembinaan anak pidana harus berorientasi pada nilai kemasyarakatan menurut penulis sesuai dengan penyelenggaraan perlindungan anak. Para pihak yaitu negara, pembina atau petugas, keluarga, dan masyarakat harus rela berkorban demi terselenggaranya perlindungan dan pemenuhan hak anak pidana. Hal ini merupakan wujud dari nilai Persatuan Indonesia. Berkaitan dengan nilai demokratik, pembinaan anak pidana harus sesuai dengan nilai dan prinsip musyawarah untuk mencapai mufakat dalam rangka perlindungan anak, mengedepankan kepentingan terbaik bagi anak.

Pembaharuan pembinaan anak pidana dalam rangka mewujudkan kepentingan terbaik bagi anak juga harus mewujudkan restorative justice. John Braithwhite mengemukakan restorative justice sebagai proses dimana semua pihak yang terlibat pelanggaran tertentu bersamasama memecahkan secara kolektif bagaimana untuk menghadapi akibat pelanggaran dan implikasinya pada waktu yang akan datang. Restorative justice bertujuan untuk memulihkan harmoni atau keseimbangan karena hukum telah ditegakkan.8 Memulihkan harmoni atau keseimbangan secara an sich saja tidak cukup, oleh karena itu "memulihkan keseimbangan" hanya dapat diterima sebagai gagasan mewujudkan keadilan jika "keseimbangan" secara moral antara pelaku dan korban yang ada sebelumnya adalah keseimbangan yang pantas. Sebagai konsep pemidanaan tentunya tidak hanya terbatas pada ketentuan hukum pidana (formil dan materiil). (Lapas, Hukum, Hak, Manusia, \& Indonesia, 2017)

Menurut pandangan restorative justice, penanganan kejahatan yang terjadi tidak hanya menjadi tanggung jawab Negara akan tetapi juga merupakan tanggung jawab masyarakat. Oleh karena itu, konsep restorative justice di bangun berdasarkan pengertian kerugian yang ditimbulkan oleh kejahatan akan dipulihkan kembali, baik kerugian yang di derita oleh korban maupun kerugian yang di tanggung oleh masyarakat. Pelaksanaan konsep restorative justice memberi banyak kesempatan kepada masyarakat untuk berperan aktif dalam penyelesaian masalah tindak pidana. Pada pelaksanaannya, anak pidana selama menjalani masa pembinaan harus terus diusahakan agar dapat tercapai hubungan baik dengan korban maupun keluarga korban sehingga pembinaan anak harus diarahkan pada rehabilitasi dan resosialisasi pelaku. Restorative Justice dalam bekerja memiliki variasi model untuk penerapannya, yaitu :

\section{a. Victim Offender Mediation (VOM)}

Victim offender mediation atau disingkat VOM adalah suatu proses yang menyediakan kemauan korban sebagai pokok dari kejahatan dan kekerasan untuk bertemu dengan pelaku, dalam suasana aman dan teratur dengan tujuan membuat tanggung jawab langsung dari pelaku 
dengan adanya bentuk kompensasi kepada korban. Program VOM pertama kali dilaksanakan pada tahun 1970 di Amerika bagian utara dan Eropa.

Program VOM dirancang dan diperbaiki selama waktu 5 (lima) tahun dengan kerangka pengertian dan pemahaman konsep restorative justice yang memusatkan perhatian pada penyelenggaraan dialog dimana korban dimungkinkan ikut serta bertukar pikiran sehubungan dengan akibat yang ditimbulkan berupa trauma dari kejahatan dan menerima jawaban dan informasi tambahan dari pelaku yang telah menyakitinya. Hal itu memberikan kesempatan bagi korban untuk mendengar dan memberikan kepada pelaku sebuah kesempatan untuk menerima tanggung jawab perbuatannya dan mengungkapkan perasaannya tentang kejahatan dan konsekuensi yang harus diterimanya.

Pada model VOM, permintaan untuk melakukan mediasi merupakan inisiatif dan usulan korban dan kehendak korban. Peserta yang terlibat dalam bentuk mediasi adalah korban (secara sukarela), pelaku, pihak yang bersimpati terhadap kedua pihak, orang tua/ wali dari kedua pihak dan orang yang dianggap penting bila diperlukan, serta mediator yang dilatih khusus.

b. Family Group Conferencing (FGC) Conferencing telah berasal dari New Zealand dan telah berkembang di negara lain seperti, Australia, Asia, Afrika Selatan, Amerika Utara dan Eropa. Conferencing tidak hanya melibatkan korban utama (primary victim) dan pelaku utama (primary offender) tapi juga korban sekunder (secondary victim) seperti anggota keluarga dan teman korban. Pihak ini ikut dilibatkan karena mereka juga terkena dampak akibat dari perbuatan yang terjadi dan memiliki kepedulian terhadap korban ataupun pelaku utama. Tugas korban sekunder adalah berpartisipasi dalam bentuk menyampaikan dan menjelaskan secara persuasif hasil kesepakatan agar dapat dilaksanakan oleh kedua belah pihak yakni korban dan pelaku.

Tujuan program FGC adalah untuk mendapatkan kejelasan dari peristiwa yang terjadi dengan memberi semangat kepada pelaku, mengembalikan kerugian korban, melakukan reintegrasi korban ke masyarakat dan pertanggungjawaban bersama. Pihak yang terlibat dalam program FGC adalah pelaku, korban, keluarga pelaku, keluarga korban masyarakat dan mediator.

Pertemuan dilaksanakan dengan memberikan kesempatan kepada para pihak untuk terlibat secara langsung untuk saling menjelaskan dalam diskusi dan membuat keputusan mengenai sanksi bagi pelaku dan membimbing pelaku pada saat mediasi berlangsung. Pelaku dan korban diharapkan dapat berhubungan untuk memperkuat kembali tatanan masyarakat yang sempat terpecah karena terjadinya pelanggaran oleh pelaku terhadap korban.

c. Circles

Circles dilaksanakan pertama kali pada tahun 1992 di Yukon, Canada. Circles sama halnya dengan conferencing yang dalam pelaksanaannya memperluas partisipasi para peserta dalam proses mediasi antara pelaku dan korban. Tujuannya membuat penyelesaian terhadap suatu tindak pidana dengan mempertemukan korban, pelaku, masyarakat dan pihak lainnya yang berkepentingan dengan terjadinya suatu tindak pidana.

Tujuan program circles adalah untuk menyembuhkan pihak yang terluka karena tindakan pelaku dan memberi kesempatan kepada pelaku untuk memperbaiki dirinya dengan bertanggung jawab untuk pemenuhan ganti kerugian.

Para pihak yang terlibat dalam circles adalah pelaku, korban, lembaga sukarela dan masyarakat. Jika kasus yang terjadi lebih serius dapat dihadirkan juga apparat penegak hukum. Kehadiran apparat penegak hukum tersebut untuk menjamin 
kelancaran pelaksanaan proses sesuai dengan prinsip restorative justice dan bukan untuk mencampuri atau melakukan intervensi pada proses yang sedang dijalankan.

Tata cara pelaksanaan circles adalah mediator melakukan pertemuan secara terpisah dengan korban dan pelaku sebagai prioritas utama. Pada pertemuan selanjutnya program circles dilaksanakan dengan cara semua pihak duduk secara melingkar, kemudian kesempatan pertama diberikan kepada pelaku untuk menjelaskan perubuatan yang dilakukannya setelah itu korban diberikan kesempatan untuk menanggapi dan setelah itu pihak lain diberikan kesempatan untuk berbicara sehingga program circles berjalan dari pihak yang satu ke pihak yang lain.

d. Reparative Board/Youth Panel

Program reparative board/ youth panel mulai dilaksanakan di negara bagian Vermont pada tahun 1996 dengan lembaga pendamping yaitu Bureau of Justice Assictance. Tujuan program reparative board/ youth panel menyelesaikan perkara tindak pidana yang dilakukan oleh anak dengan melibatkan pelaku, korban, masyarakat, mediator dan juga hakim, jaksa dan pembela secara Bersama merumuskan bentuk sanksi yang tepat bagi pelaku dan ganti rugi bagi korban atau masyarakat.

Sasarannya adalah peran serta aktif para pihak terlibat secara langsung dalam proses mediasi. Tata cara pelaksanaannya adalah mediator memfasilitasi pertemuan yang dihadiri oleh para pihak dan dihadiri juga oleh pihak pengadilan. Selama pertemuan para pihak berdiskusi dengan pelaku tentang akibat perbuatan yang dilakukan dan konsekuensi yang harus ditanggung. Berdasarkan hal tersebut, para pihak secara Bersama menentukan sanksi yang harus diberikan kepada pelaku dalam jangka waktu tertentu untuk membuat perbaikan atas akibat tindak pidanya.

Berdasarkan penjelasan di atas restorative justice yang terdapat dalam Victim Offender Mediation, Family Group Conferencing, Circles dan Reparative Board/ Youth Panel yang dikaitkan dengan teori keadilan restorative dari John Braithwhite yaitu restorative justice adalah proses dimana semua pihak yang telibat pelanggaran tertentu bersama-sama memecahkan secara kolektif bagaimana untuk menghadapi akibat pelanggaran dan implikasinya pada masa dating dapat diterapkan pada pembinaan anak pidana di Lembaga Pembinaan Khusus Anak. Variasi model yang diterapkan tergantung keadaan baik perbuatan yang dilakukan atau akibat dari perbuatan yang dilakukan untuk itu keterlibatan para pihak sangat dibutuhkan untuk mencapai tujuan (Sistem \& Nasional, 2014).

Pembaharuan pembinaan anak pidana dengan restorative justice di dalam Lembaga Pembinaan Khusus Anak juga dapat memberikan kesempatan kepada anak pidana untuk aktif membangun interaksi yang dilakukan antara korban, keluarga korban, masyarakat dalam penyelesaian konflik yang timbul. Jadi perlu ditekankan adanya kesadaran bagi para pihak untuk saling memaafkan dan mencari alternative terbaik bukan hanya menganggap pemidanaan sebagai salah satu-satunya jalan keluar.

\section{KESIMPULAN}

Berdasarkan pembahasan di atas dapat diambil kesimpulan sebagai berikut :

a. Lembaga Pembinaan Khusus Anak memiliki program pembinaan dan pelatihan, yaitu pendidikan formal dan non formal serta pembinaan konseling dan kegamaan. Program pembinaan tersebut pada praktinya masih menemukan kendala sehingga diperlukan partisipasi dari pihak lain dalam rangka memenuhi kepentingan terbaik anak. 
b. Pembaharuan pembinaan anak pidana di Lembaga Pembinaan Khusus Anak di masa mendatang harus berlandaskan Pancasila dan harus menerapkan konsep restorative justice sehingga dapat memulihkan kondisi yang terjadi di dalam masyarakat.

\section{DAFTAR PUSTAKA}

Di, A., Dalam, T., Hak, P., Manusia, A., Penelitian, B., \& Hukum, K. (2017). Peran Balai Pemasyarakatan Pada Sistem Peradilan Pidana Anak Di Tinjau Dalam Perspektif Hak Asasi Manusia (The Role Of Balai Pemasyarakatan On Juvenile Justice System Reviewed From Human Rights Perspective), 8(2), 161-174.

Hukum, J., \& Ummah, K. (2017). Jurnal Hukum Khaira Ummah Vol. 12. No. 4 Desember 2017 Tinjauan Kriminologi Dan Hukum Pidana ... (Ridha Ari Setyono), 12 (4), 967-974.

Lapas, R., Hukum, M., Hak, D. A. N., Manusia, A., \& Indonesia, R. (2017). Berita Negara, (969).

Sistem, P., \& Nasional, H. (2014). 207 Volume 4 No. 2 Februari-Juli 2014 Jurnal Ilmu Hukum, 4(2), 207-228. 